\title{
Board Diversity and
}

\section{Earning Quality: Examining the Role of Internal Audit as a Moderator}

\author{
Fathyah Hashim" ${ }^{1}$ Essia Ries Ahmed ${ }^{2}$ and ${ }^{3}$ Yeo Min Huey
}

\begin{abstract}
The purpose of this study is to explore the relationship between board diversity and the earnings quality in the firms listed in Bursa Malaysia Main Market. Malaysia is a country with multi ethnicity and different cultures among the people and this might affect positively on the quality of earning. The study also examines the involvement of the Internal Audit function being performed in-house or outsourced as a tool to enhance the earnings quality for the firms. Nationality diversity and Ethnicity diversity are found to have a significant impact on the earning quality of the sample companies. Meanwhile, Gender diversity and Age diversity does not show any significant impact on earnings quality. This study offers a significant contribution to existing earning quality literature. The participation of more different races on the board will be able to increase the quality of earning of the companies.
\end{abstract}

JEL classification: M41.

Keyword: Board diversity, Internal Audit Function, Earnings Quality.

\footnotetext{
${ }^{1}$ Universiti Sains Malaysia, Graduate School of Business

${ }^{2}$ University of Nizwa, College of Economics, Management and Information Systems

${ }^{3}$ Universiti Sains Malaysia, Graduate School of Business
} 


\section{Introduction}

Earning are one of the most crucial aspects of a business (Alabdullah, Laadjal, A., Ahmed, \& Al-Asadi, 2018). Almost all businesses will put their Return of Investment (ROI) as the first objective of the business, no matter whether it is clearly stated or a known (implicit) message (Alabdullah, Nor, \& Ries, 2018; Dror, 2017; Serra, \& Kunc, 2015). Earnings quality is defined as a measurement of how the earnings should be categorized (Hribar, Kravet, \& Wilson, 2014). High quality of earnings refers to the strong cash flow which results from a high volume of sales and lower operational or investment cost (Dechow, Sloan, \& Zha, 2014 Carvalho, Camargo, \& Kalatzis, 2017). While the earnings that are gained from aggressive accounting practices or inflation is considered as an artificial source and these earnings are categorized as low-quality earnings (Morais \& Curto, 2008). In the accounting world, earnings quality is also referred to as the ability of the company reported income (earning), further allow them to have the forecast on the company's earnings in the future (Cheng, Lee, \& Shevlin, 2015). Most of the companies set the assessment criteria to assess the earning in terms of repeatable, controllable and bankable (Christensen, Huffman, \& Lewis-Western, 2017; Bao, \& Lewellyn, 2017). This assessment is to ensure that the earnings reflect the underlying effects of the economics, and it is also a better way to estimate the cash flows of a company, which is more conservative and more predictive (Keefe, 2017). According to the fundamental qualities of GAAP (Generally Accepted Accounting Principles), there are two criteria able to help us to measure the quality of earning within a firm, which are reliability and relevance. Reliability - the measurement is able to be verified, is free from error or bias and represents the company's transactions accurately. Relevance - the measurement is timely and has predictive power; it is able to confirm or reject, prior to the predictions, and has more value when new predictions are made (Keefe, 2017).

A company's operating performance and its earnings can be measured by using two basic methods, cash accounting and accrual accounting (Li, Sougiannis, \& Wang, 2017; Dechow, Sloan, \& Zha, 2014). Cash accounting involves the recorded transactions of the firm whenever the cash enters or leaves (Abdul Rahim, Ahmed, Sarkawi, Jaafar \& Shamsuddin, 2019; Irwin, 2015). The transactions in cash accounting have been clearly recorded with the amounts involved, and this makes the method highly reliable (Jesus, \& Jorge, 2016). But, the disadvantage of cash accounting is that the measurement of earnings is not very stable, which results in low relevance (Misund, \& Osmundsen, 2015). For example, when there is new equipment bought and it is expected to be used for several years, using cash accounting will result in the inconsistent spread of cash earning across a certain period. The immediate cash outlay would reduce cash earnings early on and the lack of any cash outlay in the latter periods would increase cash earnings even though the firm used the equipment equally across all the periods (Keefe, 2017).

Accrual accounting promotes the idea of periodicity, which creates a method with higher relevance when compared to cash accounting (Gnanarajah, 2014). Periodicity states that each transaction should be assigned to a given period and split according to the covered periods. This is an attempt to recognize revenues in the period in which they were actually earned (GAAP's revenue recognition principle) as well as to match the related expenses to the earned revenue (GAAP's matching principle). However, the accrual accounting method has lower reliability when compared to the cash accounting method. The use of 
accruals exposes the recording of the transaction to uncertainty related to the principles of revenue recognition and matching (Naughton \& Spamann, 2015). This is because management's expectations and judgment are called upon to record transactions. The process of recognizing and matching creates holding accounts called accruals (accounts receivable) and allowances (allowance for bad debts) on the balance sheet (May, 2017). The amounts booked into these accounts are based on management estimates governed by accounting rules, which at times provide considerable latitude (Keefe, 2017). According to several past studies, by having good corporate governance, earnings quality can be improved (Sivaramakrishnan \& Yu, 2008; Jiang et al., 2008). However, there are only limited studies being done on the diversification of the board, and whether this will affect the quality of earning of a firm. Most of the studies are mainly focused on gender diversification within the board and it has been shown that the involvement of women in a firm has a positive effect on company earnings and performance (Fernández, 2015; Kıliç \& Kuzey, 2016; Gordini \& Rancati, 2017; García-Sánchez et al., 2017). In some situations, managers tend to use earnings management to meet the earnings forecast by analysts in their financial report (Emely, 2016). As such, they will try to avoid a strong negative share price reaction which will cause the firm's performance to fail to meet the expectations of the investors. When there is too much involvement of earnings management, the earnings quality tends to be lowered and this affects the investors' ability to interpret the current profit, especially when the earnings management is being hidden in the core earnings or has not been disclosed completely (Perotti, \& Wagenhofer, 2014). The net income in the financial report is very useful for the investor to evaluate the future performance of the firm, but, when there is too much-earnings management involved, the information becomes less useful (Mohd Radzi et al., 2011). Earnings management is known as important to accountants because it allows the accountants to understand more about the usefulness of the profit figure, and to further use it to report to investors (Burgstahler, Hail, \& Leuz, 2004). Earnings management may also be able to help the firm avoid getting themselves into some serious legal issues and to protect the reputation of the firm when they become financially distressed (Mohd Radzi et al., 2011). Burgstahler and Dichev (1997) and Degeorge, Patel and Zeckhauser (1999) find that there is a higher-than-expected frequency of firms in the US with slightly positive reported earnings (and earnings changes) and a lower-than-expected frequency of firms with slightly negative reported earnings (and earnings changes). The same pattern has been observed in the UK (Gore, Pope, \& Singh, 2002). Such discontinuities in the distributions are consistent with managers trying to beat the benchmarks in question (Peasnell, Pope, \& Young, 2005).

Although past studies have examined board diversity with corporate governance, corporate social responsibility (CSR), firm performance, and earning management, there are still limited studies which directly measure the impact of board diversity on the earnings quality of an organization. Thus, this creates a knowledge gap on how the board diversity impacts on an organization's quality of earnings. Especially in Malaysia, as a multiracial country, ethnicity diversity becomes one of the possibilities which may have impact on the performance of the companies. As from the financial report, most of the companies claimed that the companies are making profit every year, even the stock price has been found increasing linearly from time to time even when the economy of the 
country or the economy worldwide is not ideal. By analyzing the type of accounting in the companies, the quality of earnings would be able to be identified. Most importantly, to investigate whether the diversification of the board has any impact on the earnings quality? Therefore, the aim of this study is to explore the relationship between board diversity and the earnings quality in the corporate firms listed in Bursa Malaysia Main Market. In addition, this study examines the involvement of the Internal Audit Function being done in-house or outsourced and considers whether this factor would enhance the earnings quality of the companies.

\section{Issues Regarding Board Diversity}

Diversity has been defined as the condition that is having or being composed from different elements, a variety (Santana, 2017). Diversification is also being used to describe the group of people who are different types of people in terms of different cultures, different races, different backgrounds etc. (Ararat et al., 2010). As such, board diversity is referring to the diversification within the board. Often, when people look into board diversity, they only focus on gender diversification; but, in fact, the real diversification is involving the cultures, races, educational background, ethnicity, nationality and more. There are plenty of international organization that have introduced board diversity to their board of management and their board of directors. Malaysia is a country with multiple ethnicities. In 2016, there were an estimated 31.7 million people as the total population of Malaysia, an increase of 0.5 million people compared to the year 2015 with the 31.2 million number of population, and a 1.5 percent growth rate of the population when compared to the same period. Among all Malaysians, ethnic diversity includes Bumiputra ${ }^{1}$ (Malay and Indigenous) which constitutes the highest percentage with $68.6 \%$, followed by Chinese $(23.4 \%)$, Indians $(7.0 \%)$ and others $(1.0 \%)$. Furthermore, the percentage of non-Malaysian citizens in 2016 was $10.3 \%$ of the total Malaysia population.

The distribution of population by age groups in the year 2016 showed no significant difference as compared with the year 2015 (Department of Statistics Malaysia, 2016). Population in the group 0-14 years old decreased $0.4 \%$ at $2016(24.5 \%)$ when compared to 2015 (24.9\%). The working age population, 15-64 years old, increased by $0.2 \%$ in 2016 when compared to 2015. Other than that, the population aged 65 years and above was also increased by $0.2 \%$ compared to the same period in 2015 (Department of Statistics Malaysia, 2016). While for gender, the male to female ratio for the group of age 15-24 years is 1.03:1; for the group of 25-54 years is 1.02:1 and for the group of 55-64 years is 1.03:1 (Malaysia Demographics Profile 2016, 2016). These data have shown us the number of working adults and the different ethnicity which possibly involve in any of the management board of any firm within Malaysia, and here, we need to know is there any effect the diversification of the management board will affect the earning quality of an organization. By knowing the impact of board diversity on the earnings quality of a firm, we will be able to improve the earning quality if there is any positive impact, or vice versa. Diversification on boards has been gaining much attention for several years, as one of the crucial issues in ensuring good governance in any corporation (John, Makhija \& Ferris, 2014). The proper governance of firms requires optimal board composition. In 
fact, there many researchers around the world focussing on that question. A cottage industry (2) of studies has explored this issue, as well as the role of diversity in organizational contexts more generally (Rhode \& Packel, 2014). In the aftermath of corporate scandals in different countries, such as Enron, WorldCom, and Tyco International in the United States, HIH Insurance in Australia, and Parmalat in Italy, a number of practitioners have called for board diversity (Ujinwa et al, 2012). Gender, racial, and cultural composition of the board of directors has become one of the most significant governance issues currently facing the managers, directors, and shareholders of the modern corporation. This issue has taken a high public profile because of reports in the popular press, shareholder proposals from advocacy groups, and policy statements from major institutional investors (Carter et al., 2003). There are plenty of articles reflecting the interest in board diversity. The term managing diversity was popularized largely by the publication of Kandola and Fullerton's book aimed at practitioners. Since then, diversity management, or simply diversity policy has become the typical label in the organisations for policies and practices that would once have fallen under the heading of equal opportunities or simply equality policy (Kirton \& Greene, 2010). However, most corporate directors are still middle aged white males in well-known leading companies around the world. In 1973, just $11 \%$ of boards featured even one woman, and $9 \%$ had a director from an ethnic minority. In 1998, Spencer Stuart offered the bold headline: Boards Eager to Recruit More Women (Monks and Minow, 2003). Throughout history, including in the most recent century, women have been underrepresented in business and societal leadership everywhere in the world. At the close of the 20th century, women held less than $3 \%$ of the most senior management positions in major corporations in the United States and less than $2 \%$ of senior management positions in Europe. In many countries, the proportion of women executives never made it above 1\%. In Italy, for example, only $0.1 \%$ of senior managers were women. Such scarcity is no longer an option for societies and companies hoping to prosper in the 21 st century (Adler, 2007).

$90 \%$ of female directors believe that women bring special attributes to the board, whereas only $56 \%$ of male directors believe this to be true. Similarly, $51 \%$ of women believe that having three or more female directors on a board makes it more effective, whereas only $12 \%$ of male directors hold this opinion. Nevertheless, despite the difference of opinions, companies have made significant efforts toward recruiting diverse board members (Larcker and \& Tayan, 2011). According to Spencer Stuart's research (Stuart, 2012), $75.1 \%$ of the companies have taken steps to support/promote boardroom diversity initiatives within the last three years, $63 \%$ of the companies ask search firms to include diverse candidates, $56.5 \%$ have proactively included boardroom diversity as a board meeting agenda topic and 50\% have a board diversity policy that includes a general statement supporting diversity. Regarding the increased value for shareholders, $79.9 \%$ believe that diversity in the boardroom generally results in increased value for shareholders. Still, 66.7\% agree that boardroom diversity should never be mandatory always voluntary. Given the emphasis being placed on board diversity as a part of the framework for good earnings quality, the relationship between board diversity and earnings quality deserves both theoretical and empirical investigation. Even though there exists organizations without any diversification within their board, there are still a few past studies which have examined the effect of board gender diversity on corporate 
performance (Carter et al. 2003; Ujinwa et al., 2012; Firdanoski et al, 2014; Fernández, 2015), corporate social responsibility (Ibrahim \& Mohd Hanefah, 2016), and also on financial performance (Gordini \& Rancati, 2017).

\section{Literature review}

In order to have an effective organization, everyone who is involved in the organization plays an important role. Thus, the board of directors will act as the soul character for a firm and bring the organization to achieve its business objectives. As such, there are many studies being done on the relationship of the diversification in the board and the firm's performance. These allow us to have more knowledge on the effect of the diversification of the directors on the company's performance in terms of operational and financial.

\subsection{Board Diversity}

In recent years, board diversity has been categorized as one of the most important governance issues (Barako \& Brown, 2008). However, the demand for more diversified board became more urgent due to the increase of diversity in the workforce in terms of gender, ethnicity and age (Darmadi, 2011). Board diversity is an advantage to an organization as it improves the corporate leadership effectiveness, helps to develop a better understanding within the marketplace, at the same time provide legitimacy to the companies, builds global relationships and finally enhances corporate governance (Walt \& Ingley, 2003; Erhardt et al., 2003; Carter et al., 2007). From the perspective of agency theory, a more diverse a board is, it will lead to better monitoring of management because board diversity leads to increased board independence (Carter et al., 2007). Thus, companies tend to disclose more information to reduce agency costs, reduce the information asymmetry and to protect their reputation (Lim et al., 2007; Htay et al., 2012).

On the other hand, resource dependence theory suggests that board diversity will increase the resources provided by board members, such as skills, information, legitimacy and access to key constituents (e.g. suppliers, buyers, public policy decision-makers and social groups) (Hillman et al., 2000). In such, the diversification of the board of directors in terms of age, gender and ethnicity, would be able to provide unique information to the management for better decision-making (Ayuso \& Argandoña, 2007). These can impact the earning quality of a firm. While, according to Ferdinand et al. (2011), gender diversity helps in improving the stock price informative-ness through the increased of public disclosure in large companies and by encouraging the collection of private information in small companies. These past studies use one or more attributes as proxies for board diversity. For example, (Barako and Brown (2008) and Khan (2010) studied female and foreign directors. Meanwhile, Post et al. (2011) examined different age groups and female directors. Gender diversity was the most widely observed attribute studied. Despite this, Jordanian women lead other Arabic women in terms of literacy rates and are classified amongst the top five in the Middle East and North Africa (MENA) countries (Bank, 2005). There are many legal frameworks that support and ensure women's equality and rights in Jordan. No matter what the achievements of Jordanian women in many areas, they still face obstacles in the labor market, such as wage differences, unemployment and underemployment rate, when compared to men. For example, men earn $23 \%$ more than women in management positions (UNDP, 2011). 


\subsubsection{Gender Diversity}

Gender diversity has become part of the broader concept of board diversity (Carter et al., 2003). It is referring to the presence of female directors in the company's boards of directors. Women directors bring diverse perspectives, experiences and working styles to the board (Daily, 2003), which helps to enhance the discussion in the board, and further improve the decision-making (Carter et al., 2003). The majority of studies also revealed a positive relationship between the number of women on the board and the firm's financial performance. Kılıç and Kuzey (2016) found in their study that the inclusion of female directors in the board is positively related to the financial performance of firms, as measured by the return on assets, the return on equity and the return on sales. Another study found that greater gender diversity may generate economic gains, and also does not destroy shareholder value, but, rather, it may effectively influence investors' evaluations of the future earning potential of firms that have more female directors (Post \& Byron, 2015; Gordini \& Rancati, 2017). However, several past studies found a negative relationship between gender and the quality of earning. For instance in Indonesia, it was found that the representation of female top executives is negatively related to both ROA and Tobin's q, suggesting that female representation is not associated with an improved level of performance (Darmadi, 2013). Similarly, Kreder (2016) using a sample of S\&P 1500 companies between 2007 and 2014 from US-listed firms, found that the presence of female in the board is strongly associated with a decrease in discretionary revenue recognition, and this association is stronger for firms with higher percentages of board positions occupied by female directors (Kreder, 2016).

Krishnan and Parsons (2008) suggest that the improved bottom line for companies with more women senior executives is not produced through the management of earnings or lower quality earnings. Instead, earnings quality is positively associated with gender diversity in senior management (Krishnan \& Parsons, 2008). There is a study on the link between the gender diversity of the board and firm financial performance in Spain, and it suggests that the companies which increase their female member in the board and greater the gender diversity may generate economic gains (Campbell \& Mínguez-Vera, 2008). Carter et al. (2010) found that there is no significant relationship between the gender or ethnic diversity of the board, or important board committees, and financial performance for a sample of major US corporations. (Carter et al., 2010). Based on this literature, the following hypothesis has been developed:

H1: There is a positive relationship between the proportion of female directors on the board and the quality of earnings.

\subsubsection{Nationality Diversity}

In terms of nationality diversity, there are several governance guidelines which support the appointment of different nationalities on the board of directors to reflect the nationality diversity of their customers, employees and stakeholders (Fidanoski, Simeonovski, \& Mateska, 2014). The appointments of foreign directors are also seen to 
be able to improve the quality of the decision-making within the board (Van den Berghe \& Baelden, 2005; Davies, 2000). Resource dependence theory suggests that foreign directors able to provide diverse opinions, having different culture and behavior, and also the different life experience, and these may be able to improve the decision-making and also the company's strategies (Ruigrok et al, 2007; Ayuso \& Argandona, 2007). Foreign directors were being argued to provide diverse opinions and perspectives, such as culture, language, life experiences, religion, behavior and norms of the country or region, which would be able to enhance the decision-making process (Ruigrok et al., 2007). Ayuso and Argandona (2007) claimed that the foreign directors' knowledge helps to improve the decisions of a company's strategy, for example, supporting CSR reporting strategies and at the same time will increase board capital (which ultimately may lead to better financial performance). Thus, the second hypothesis for this study is stated as below:

H2: There is a positive relationship between the proportion of foreign nationals on the board and the quality of earnings.

\subsubsection{Ethnic Diversity}

In terms of ethnic diversity, when there are ethnic minority directors on the board, the diversity of board composition appears to create value for shareholders ( Gyapong, Monem, \& Hu, 2016; Gyapong, Monem, \& Fang, 2015). The results of a cross-section fixed-effects procedure with lagged variables and a three-stage least squares estimation support board diversity has a positive effect on financial performance as measured by Tobin's q For example, Carter, Simkins, and Simpson (2003; 2007) and Adams and Ferreira (2009). However, the board committee evidence from a study done by Carter et al. (2007), indicates that the process through which gender and ethnic diversity impact financial performance is subtle and complex. Some functions of the board may benefit from diverse directors while other functions may actually suffer (Carter et al., 2007; 2010). Moreover, when there is diversification of ethnicity interacted with business strategy, the firm performance will be measured in three different ways, as productivity, return on equity, and market performance. A Richard (2000) show that cultural diversity does, in fact, add value and, within the proper context, contributes to firm competitive advantage. Accordingly, the study makes the following hypothesis:

H3: There is a positive relationship between the proportion of different ethnicity on the board and the quality of earnings.

\subsubsection{Age Diversity}

According to Sonnenfeld (2002) and Darmadi (2011), age can be seen as an asset to the board and is considered as part of human capital, because age can reflect experience and risk-taking. However, in today's corporate world, most of the board members are at an elder age, and the involvement of young directors is every minute (Gilpatrick, 2000). Appointing young directors might bring in different ideas and perspectives to the 
company. There is an argument stated that younger directors are having a higher ability to process new ideas and are more innovative (Ness et al, 2010). Furthermore, they are more positively related to strategic change and more willing to participate in the monitoring process (Darmadi, 2011). This will be able to enhance the performance of the board and decision-making. Thus, this study hypothesize as follows:

H4. There is a positive relationship between the proportion of young directors on the board and the quality of earnings.

\subsection{Internal Audit Function}

The role of internal audit has evolved over time, from a role that was traditionally assurance-related, to a function that is more value-added in nature (Bou-Raad, 2000; Krogstad et al., 1999). From an external audit perspective and International Standard on Auditing 610 (revised 2013 - using the work of internal auditors), external auditors can use the work of internal auditors only if certain conditions are met. The use of internal audit work may have implications on the nature or timing, or the extent, of audit procedures to be performed directly by the external auditor. BameAldred et al. (2013) in their synthesis on external auditor reliance on the internal audit function, state that there is lack of research concerning the effects of external auditor's reliance on the internal audit function in terms of external auditor quality. there has been little attention paid to another well-regarded internal monitoring mechanism - the internal audit function. In recent years, the internal audit function has received significant attention from policy makers where many governance regulatory guidelines and stock exchange listing requirements specifically advocate the establishment of the internal audit function (Johl, Kaur Johl, Subramaniam, \& Cooper, 2013). Nevertheless, to date, only a few studies have examined the association between internal audit and earnings management and the results from these two studies are inconsistent. The first by Davidson et al. (2005), using a sample of Australian firms, did not find evidence that the presence of an IAF is related to lower earnings management. The second study by Prawitt et al. (2009), specifically considered several quality dimensions of the internal audit function and using data from US firms, revealed that internal audit function quality is negatively associated with abnormal accruals (a proxy for earnings management/quality). They also found that firms that just miss analysts' expectations have a significantly higher internal audit function quality. Using a different methodology, Gras-Gil et al. (2012) in the context of Spanish banks, find that banks with high quality financial reporting have better cooperation between internal and external auditors in the annual audit. Specifically, they find that greater participation of internal audit in the review of the financial reporting process leads to improved quality financial reporting. The Material Weakness disclosures are found to be positively associated with the Internal Audit practice of grading audit engagements and together with the external-internal auditor coordination, suggested that the activities able to increase the effectiveness of Section 404 compliance processes (Shu Lin et al., 2011). While Inaam and Khamoussi (2016) found that the independence of the audit committee, the size of the audit committee, the expertise and the number of meetings held have a 
negative relationship with earnings management. Similar relationships exist between the auditor size, specialization and earnings management.

H5: There is a positive impact resulting from the interaction between the board diversity and the Internal Audit Function on the quality of earnings.

\subsection{The Underlying Theory (Resource Dependence Theory)}

Resource dependence theory provides a key argument for board diversity. The theory suggests that board diversity brings new insights and perspectives to the firm and increasing creativity and innovation (Walt \& Ingley, 2003; Carter et al., 2007; Miller \& Triana, 2009). There are three core ideas of the theory: (1) social context matters; (2) organizations have strategies to enhance their autonomy and pursue interests; and (3) power (not just rationality or efficiency) is important for understanding internal and external actions of organizations (Davis \& Cobb, 2015). Accordingly, more diverse board members lead to better understanding and problem solving, enabling the board to effectively address the business environment and encourage positive ratings for Corporate Social Responsibility (CSR) (Bear et al., 2010). There are several studies have examined the relationship between gender diversity and earning quality or with financial performance (Walt \& Ingley, 2003; Carter et al., 2003; Carter et al., 2010; Ferdinand et al., 2011; Darmadi, 2011; Fidanoski et al., 2014; Kılıç \& Kuzey, 2016; García-Sánchez et al., 2017; Gordini \& Rancati, 2017).

\subsection{Theoretical Framework}

This study is measured on the Board Diversity (Independent Variable, IV) and the Earning Quality (Dependent Variable, DV). The IV has been divided into four; the gender, nationality, ethnicity and age, and they are directly measured with the earning quality. The Internal Audit Function act as the moderator in this study, to examine whether there is any positive impact brought to the earning quality, on top of the impact from the board diversity (see Figure 1).

\section{Methodology}

This study uses quantitative methods, secondary data which has been collected from the annual reports from the year 2016, of the public listed companies in Malaysia, through Bursa Malaysia, for all the sampled companies. The annual report is used to collect the data as it provides a high level of credibility, availability and accessibility (Tilt, 1994; Adams et al., 1998). The study was testing between board diversities of gender, nationality, age and ethnicity with the earning quality of the company, and whether the internal audit status able to moderate the effects of the board diversity on the earning quality. The population of this study consists of all 745 companies listed in the Main Market of Bursa Malaysia, excluding the industry involved in financial trading, e.g. banks, insurance providers and Real Estate Investment Trust (REITs) (Bursa Malaysia Main Market, 2017). The reason of excluding the finance sector in this study is because of the way they present their financial performances are different from other sectors, the 
exclusion of these companies is to ensure a balanced comparison in the observation. The samples are drawn from the public listed companies listed in Bursa Malaysia for the year 2017 from various industries, namely, Hospitality, Industrial, Trading and Services and others. There are some companies being excluded due to unpublished annual report or inconsistency of financial statement presentation, which some of the companies have reported more than 12 months of financial performance for the year. The final samples consisted of a total of 90 companies and were randomly selected by using the random sampling method. The samples are representing $12 \%$ of the whole population.

Measurement of Variables: In this study, board diversity act as the independent variable, and there are four (4) independent variables were measured; which are the gender diversity, nationality diversity, ethnicity diversity and age diversity. In such, the board of director have been categorized accordingly to the different variables for the 90 sample companies. For the gender diversity, the directors are categorized into male or female; for nationality diversity, they have been categorized into Malaysian or Foreigner; for ethnicity diversity, the directors are categorized into Chinese, Indian, Malay, or Others; while for the age diversity, they have been categorized into younger or equal to $45(\leq 45)$ years old or elder than $45(>45)$ years old. All the independent variables are measuring in terms of proportion (ratio), as illustrated in the following:

$$
\begin{gathered}
\text { Ratio of female director }=\frac{\text { Number of female director }}{\text { Total number of director }} \\
\text { Ratio of foreign director }=\frac{\text { Number of foreign director }}{\text { Total number of director }} \\
\text { Ratio of Chinese director }=\frac{\text { Number of Chinese director }}{\text { Total number of director }} * * \\
\text { Ratio of young director }=\frac{\text { Number of young director }}{\text { Total number of director }}
\end{gathered}
$$

**Applicable to Indian, Malay, and Other Races director

These variables have been tested in several past studies (e.g. in Walt \& Ingley, 2003; Carter et al., 2003; Ayuso \& Argandoña, 2007; Richard, 2000; Carter et al., 2010; Ferdinand et al., 2011; Darmadi, 2011; Fidanoski et al., 2014; K1lıç \& Kuzey, 2016; García-Sánchez et al., 2017; Gordini \& Rancati, 2017). To assess the dependent variable, which is the earning quality of the companies, Modified Jones Model has been used to check is there any earning being managed in the company, the bigger value of the score get in earning management, the worse the quality of the earning in the company. Thus, is better to get a negative score in earning management, indicate that the earning has not being managed. First, the total accruals of the year were calculated using the formula as illustrated in the following:

$\operatorname{TACC} \tau=\Delta \operatorname{CA} \tau-\Delta \operatorname{Cash} \tau-\Delta \operatorname{CL} \tau+\Delta \operatorname{STDebt} \tau$ 
Where

$\operatorname{TACC} \tau=$ Total accruals in year $\tau$

$\Delta \mathrm{CA} \tau \quad=$ Change in current assets in year $\tau$

$\Delta$ Cash $\tau=$ Change in cash and cash equivalents in year $\tau$

$\Delta \mathrm{CL} \tau=$ Change in current liabilities in year $\tau$

$\Delta$ STDebt $\tau=$ Change in short term debt included in current liabilities in year

$\tau$

Then, the earning management score were calculated using the formula as illustrated in the following:

$\mathrm{TACC} \tau /\left(\mathrm{A} \tau_{-1}\right)=\beta 1 \quad 1 /\left(\mathrm{A} \tau_{-1}\right)+\beta 2 \Delta \mathrm{REV} \tau /\left(\mathrm{A} \tau \tau_{-1}\right)+\beta 3 \mathrm{PPE} \tau /\left(\mathrm{A} \tau_{-1}\right)+\mathcal{E} \tau$

Where

$\operatorname{TACC} \tau=$ Total accruals in year $\tau$

$\mathrm{A} \tau \tau_{-1} \quad=$ Total assets in year $\tau-1$

$\Delta \operatorname{REV} \tau=$ Change in sales revenues in year $\tau$

$\operatorname{PPE} \tau=$ Property, plant and equipment in year $\tau$

$\mathcal{E} \tau \quad=$ Residuals in year $\tau$ (earning management score)

$\beta 1-\beta 3 \quad=$ Coefficients to be estimated, namely betas.

Measurement of moderating variable (the Internal Auditing function) is based on the dummy in house or outhouse (outsourced).

Multiple Regression Analysis has been used to analyse the relationship between the independent variables and the dependent variable. On top of that, Internal Audit act as the moderating variable, to test on whether the Internal Auditing being carried out in house or being outsourced will be able to improve or deteriorate the earning quality on top of the impact from the independent variables. Then, Hierarchical Multiple Regression has been used to analyse is the moderating variable helps to improve the earnings quality, on top of the independent variables. Furthermore, Descriptive analysis has been used to analyse all the variables.

\section{Findings and Discussion}

Table 2 presents the descriptive analysis statistics for the variables for all the 90 companies for the year 2016. In general, it is noted that the EM has the mean of 0.0043 , this indicates that most of the companies in the sample group have at least managed a little of the earning when presenting the figures in the financial statement. In such, this also indicates that the companies are having a generally low quality of earnings. The female directors present on the board are only around $10 \%$ according to the analysis, with the minimum value of 0 and the maximum value of $62.5 \%$. 
The results also show that 52 out of 90 companies have at least one female member on the board, representing $57.78 \%$ of all companies. This is considered low as according to Larcker and Tayan, there have to be at least three or more female directors in the board to make it more effective (Larcker \& Tayan, 2011). There are averagely $6 \%$ of foreign directors involved in the board for each of the companies, and the rest are Malaysian.

In terms of ethnicity, there are generally $59 \%$ of Chinese directors in the board, which is more than half; $3 \%$ of Indian directors, $34 \%$ of Malay directors and 3\% of other races involved in the board. Out of the 90 samples, there are only 9 companies are having more than 10 directors, this indicates that there are only one Indian director and 1 foreign director involved in the board, the rest of them are either Chinese or Malay. In such, the ethnicity diversity of the board is very low.

In terms of Age diversity, there are only $12 \%$ out of the total directors are younger than or equal to 45 years old. This shows that the majority of the board of directors are not young. Most of the young directors are the sons or daughters of the owner of the company. Only less than 10 of them are having no relationship with the other directors on the board. On the other hand, it is also noted that only $44 \%$ of the total sample companies are performing their Internal Audit Function in house, the rest of the companies have outsourced the Internal Audit Function to the service providers.

Where

$\begin{array}{ll}\text { EM } & =\text { Earning Management } \\ \text { GEND } & =\text { Female Director } \\ \text { NAT } & =\text { Non-Malaysian Director } \\ \text { ETHC } & =\text { Chinese Director } \\ \text { ETHI } & =\text { Indian Director } \\ \text { ETHM } & =\text { Malay Director } \\ \text { ETHO } & =\text { Other Races Director } \\ \text { AGE } & =\text { Young Director }(\text { Age } \leq 45 \text { years old) } \\ \text { IA } & =\text { Internal Audit being done In-House }\end{array}$

Table 3 shows that the foreign nationals in the board do have a significant positive association with the companys' earnings quality $(\mathrm{p}=0.044)$, supporting H2. On top of that, the t-value for foreign nationals is more than 2 , indicates that there is good evidence to accept the hypothesis and there is a significant difference. The closer the t-value to 0 , the more likely there is no significant difference. According to the resource dependence theory, this outcome is in line as the theory suggested that foreign directors able to provide diverse opinions, having different culture and behaviour, and also the different life experience, and these may be able to improve the decision-making and also the company 's strategies (Ruigrok et al, 2007; Ayuso \& Argandona, 2007). The foreign directors who where involved in the study, the majority of them are Singaporean, and some others are from Taiwan, China, Australia, Dutch, Argentina, Japan etc. These foreign directors may have different background and experiences in their industry and this may help in making a difference in the performance of their company. The involvement of foreign directors may enhance the financial performance, and results in a better quality of earning for their firms, therefore, $\mathrm{H} 2$ accepted.

At the same time, out of the four ethnicities, only the presence of Indian directors in the board makes a significant difference $(p=0.076)$ to the earning quality of the company. The $t$-value for the Indian directors is further away from $0(t=-1.796)$, indicate that there is a significant difference. $\mathrm{H} 3$ states that there is a positive relationship between the multi 
ethnicity directors and the earning quality of the company, thus, H3 can be accepted. There is no statistically significant relationship between the Chinese directors $(p=0.531)$ and Malay directors $(\mathrm{p}=0.535)$ with the earning quality of the companies. The t-value for Chinese directors and Malay directors are 0.629 and 0.623 respectively. This indicates that most of the directors on board are majority Chinese and Malay. This may also be causing the insignificant results as the races proportion of the directors are generally balanced in the board. And, although the Chinese and Malay directors are from different ethnicity, in Malaysia, both races share a similar culture and background as Malaysia is known as a multi ethnicity country, and each of the races influenced each other and most of the time they share a similar culture with each other. While there is no statistically significant relationship between the other races director and the earning quality of the firms $(p=0.223)$ but with the t-value of -1.228 . This may be due to the low number of other races directors on the board and it is not strong enough to have an impact on the earnings quality of the companies.

In terms of gender diversity, the findings have shown a not significant $p$-value $(p=0.629)$. This may be due to the low number of female directors involved in the board. There are only 71 female directors out of the total of 670 directors from all the 90 sample companies. It is only representing $10.6 \%$ of the total directors and is not in line with the suggested minimum number of female directors' involvement in the board by Larcker and Tayan (2011). Hence, H1 rejected. There is also no significant relationship between age diversity and the earnings quality in this study $(\mathrm{p}=0.891)$. This may be due to the low number of young directors involved in the board. There are only 82 directors with $\leqslant$ 45 years old, out of the total of 670 directors from all the 90 sample companies, representing $12.24 \%$ of the total directors. Most of the young directors are the sons or daughters of the owner of the companies. Thus, it may be a strong possibility that the owners place their children onto the board to gain experience for future company management. There are only a small number of the young directors are having no relationship with the other board members, but it may be too minimal to have an impact on the earnings quality of the companies. Thus, H4 rejected.

On top of that, generally, there is no statistical difference found by applying Internal Audit Function as moderator. All the interactions of Moderating Variable (MV) withIndependent Variables (IV) showed insignificant ( $p>0.10)$, indicates that there is no significant difference in the earning quality when the Internal Audit Function being done in-house or being outsourced. The results showing as insignificant may be due to all of the sample companies having an Internal Audit Function, no matter whether in-house or outsourced, this function has been done with a similar level of quality. Thus, when there is no difference in the quality of the Internal Audit Function, then there will be no significant impact on the earnings quality on top of the impact from independent variables.Therefore, H5 rejected.The R2 has been improved from 0.103 (Model 1) to 0.074 (Model 3). This means that the predictor has improved the model by less than expected by chance.

\section{Limitations and Conclusion}

There is a time limitation; therefore, only $11 \%$ of the total population are involved in this study, as the time for data collection is limited. Thus, a future study should cover a bigger sample size to have a clearer picture of the impact from the independent variables to the dependent variables. There is also a limitation on the moderating variable, although the 
Internal Audit Function was carried out either in-house or was outsourced, it shows no significant difference. Therefore, a study that involved those company without Internal Audit Function, neither in house nor outsourced would be suggested to carry out in the future to have an idea on whether the presence of Internal Audit Function (IAF) will be able to improve the earning quality if the IAF being implemented. This study has examined the relationship between board diversity and the earnings quality of the companies listed in the Bursa Malaysia Main Market. The study has contributed to the existing literature of earning quality by examining the ethnicity diversity in the Malaysia context, as Malaysia is known as a multiracial country. The board diversity variables, namely, nationality diversity and the ethnicity diversity in the board, were found to have an impact on the earning quality of the company. While gender and age diversity was found not to affect earnings quality much. In general, board diversity was found to have a positive impact and to significantly affect the earnings quality of the companies listed in Bursa Malaysia Main Market. This indicates that the companies with higher diversification of the board are more likely to have a higher quality of earnings. Although the Internal Audit Function does not show a significant impact in this study, still there are several studies showing that the Internal Audit Function does play an important role in company performance, either in social or financial terms. Thus, the involvement of the Internal Audit Function in the company operation is still crucial. The findings enable the firms in Malaysia to have a rough idea on how the proportion of their board members is should be and allow them to have a more diversified board, and further improve the earning quality of the company.

\section{References}

Abdul Rahim, N. F., Ahmed, E. R., Sarkawi, M. N., Jaafar, A. R., \& Shamsuddin, J. (2019). Operational risk management and customer complaints: the role of product complexity as a moderator. Benchmarking: An International Journal, 26(8), 24862513.

Adler, N. J. (2007). One world: Women leading and managing worldwide. In D. Bilimoria \& S. K. Piderit (Eds.), Handbook on women in business and management. Northampton: Edward Elgar.

Alabdullah, T. T. Y., Laadjal, A., Ahmed, E. R., \& Al-Asadi, Y. A. A. (2018). Board Features and Capital Structure in Emerging Markets. Journal of Advanced Management Science Vol, 6(2).

Alabdullah, T. T. Y., Nor, M. I., \& Ries, E. (2018). The determination of firm performance in emerging nations: Do board size and firm size matter?. Management, 5(3), 57-66.

Ararat, M., Aksu, M. H. and Tansel Cetin, A. (2010). Impact of Board Diversity on Boards' Monitoring Intensity and Firm Performance: Evidence from the Istanbul Stock Exchange. SSRN, 1-33.

Ayuso, S. and Argandoña, A. (2007). Responsible corporate governance: towards a stakeholder board of directors? Spain: Working Paper No 701, IESE Business School- University of Navarra. 
Bank, W. (2005). The Economic Advancement of Women in Jordan: A Country Gender Assessment. Washington, DC: Social and Economic Development Group, Middle East and North Africa Region (MENA).

Barako, D.G. and Brown, A.M. (2008). Corporate social reporting and board representation: evidence from the Kenyan banking sector. Journal of Management Governance, 309-324.

Bear, S., Rahman, N. and Post, C. (2010). The impact of board diversity and gender composition on corporate social responsibility and firm reputation. Journal of Business Ethics, 207-221.

Bursa Malaysia Main Market. (2017). Retrieved from Bursa Malaysia: http://www.bursamalaysia.com/market/listed-companies/list-ofcompanies/main-market/

Campbell, K. and Mínguez-Vera, A. (2008). Gender Diversity in the Boardroom and Firm Financial Performance. Journal of Business Ethics, 435-451.

Carter, D. A., D'Souza, F., Simkins, B. J. and Simpson, W. G. . (2010). The Gender and Ethnic Diversity of US Boards and Board Committees and Firm Financial Performance. Corporate Governance: An International Review, 396-414.

Carter, D. A., D'Souza, F., Simkins, B. J. and Simpson, W. G. (2007). The Diversity of Corporate Board Committees and Firm Financial Performance. SSRN, 1-40.

Carter, D. A., Simkins, B. J., and Simpson, W. G. (2003). Corporate governance, board diversity, and firm value. Financial Review, 38(1), 33-53.

Daily, C. a. (2003). Women in the board room: a business imperative. Journal of Business Strategy, 8-9.

Darmadi, S. (2011). Board diversity and firm performance: the Indonesian evidence. Corporate Ownership and Control Journal, 524-539.

Darmadi, S. (2013). Do women in top management affect firm performance? Evidence from Indonesia. Corporate Governance: The international journal of business in society, 288-304.

Davis G. F. and Cobb J. A. (2015). Chapter 2 Resource dependence theory: Past and future. In Stanford's Organization Theory Renaissance, 1970-2000, 21-42.

Dictionary, M.-W. (n.d.). Merriam-Webster.com. Retrieved from Merriam-Webster.com: https://www.merriam-webster.com/dictionary/diversity

Erhardt, N.L., Werbel, J.D. and Shrader, C.B. (2003). Board of director diversity and firm performance. Corporate Governance: An International Review, 102-111.

Ferdinand, A. G., Srinidhi, B. and Ng, A. C. (2011). Does board gender diversity improve the informativeness of stock prices? Journal of Accounting and Economics, 314338.

Fernández, J. (2015). The impact of gender diversity in foreign subsidiaries' innovation outputs. International Journal of Gender and Entrepreneurship, 148-167. 
Fidanoski, F., Simeonovski, K. and Mateska, V. (2014). The Impact of Board Diversity on Corporate Performance: New Evidence from Southeast Europe. Corporate Governance in the US and Global Settings, 81-123.

García-Sánchez, I. M., Martínez-Ferrero, J. and García-Meca, E. (2017). Gender diversity, financial expertise and its effects on accounting quality. Management Decision, 347-382.

Gilpatrick, K. (2000). Invite youthful insight. Credit Union Management, 28-29.

Gordini, N. and Rancati, E. (2017). Gender diversity in the Italian boardroom and firm financial performance. Management Research Review, 75-94.

Htay, S.S.N., Rashid, H.M., Adnan, M.K. and Meera, A.K.M. (2012). Impact of corporate governance on social and environmental information disclosure of Malaysian listed banks: panel data analysis. Asian Journal of Finance and Accounting, 1-24.

Ibrahim, A. H. and Mohd Hanefah, M. (2016). Board diversity and corporate social responsibility in Jordan. Journal of Financial Reporting and Accounting, 279298.

Inaam, Z. and Khamoussi H. (2016). Audit committee effectiveness, audit quality and earnings management: a meta-analysis. International Journal of Law and Management, 179-196.

Jiang, W., Lee, P., and Anandarajan A. (2008). The association between corporate governance and earnings quality: Further evidence using the GOV-Score. Advances in Accounting, 191-201.

Keefe, T. (2017). Earnings Quality: Defining "Good Quality". Retrieved from Investopedia.com: http://www.investopedia.com/university/accounting-earningsquality/earnings 2 .asp

Khan, M. (2010). The effect of corporate governance elements on corporate social responsibility (CSR) reporting: empirical evidence from private commercial banks of Bangladesh. International Journal of Law and Management, 82-109.

Kılıç, M. and Kuzey, C. (2016). The effect of board gender diversity on firm performance: evidence from Turkey. Gender in Management: An International Journal, 434455.

Kirton, G., and Greene, A. (2010). The dynamics of managing diversity: A critical approach. Oxford: Elsevier.

Kreder, R. (2016). Board diversity and Earnings quality: The association between female board presence and the magnitude of discretionary revenue activities, evidence from US-listed firms. Rotterdam, Netherlands: Erasmus University Rotterdam, Erasmus School of Economics, Accounting Auditing and Control.

Krishnan, G.V. and Parsons, L.M. (2008). Getting to the Bottom Line: An Exploration of Gender and Earnings Quality. Journal of Business Ethics, 65-76. 
Larcker, T., and Tayan, B. (2011). Corporate governance matters: A closer look at organizational choices and their consequences. Upper Saddle River, NJ: Pearson Education.

Lim, S., Matolcsy, Z. and Chow, D. (2007). The Association between board composition and different types of voluntary disclosure. European Accounting Review, 555583.

(2016). Malaysia Demographics Profile 2016. Malaysia: CIA World Factbook.

Malaysia, T. O. (2016). Press Release - Current Population Estmates, Malaysia, 20142016. Malaysia: Department of Statistics Malaysia.

Miller, T. and Triana, M. . (2009). Demographic diversity in the boardroom: mediators of the board diversity - firm performance relationship. Journal of Management Studies, 755-786.

Mohd Radzi, S. N. J., Islam, Md. A. and Ibrahim, S. (2011). Earning Quality in Public Listed Companies: A Study on Malaysia Exchange for Securities Dealing and Automated Quotation. International Journal of Economics and Finance, 233-244.

Monks, R. A. G., and Minow, N. (2003). Corporate governance. Malden, MA: Blackwell.

Morais, A. I. and Curto, J. D. (2008). Accounting Quality and the Adoption of IASB Standards - Portuguese Evidence. Revista Contabilidade \& Finanças, 103-111.

Ness, R.K., Miesing, P. and Kang, J. . (2010). Board of director composition and financial performance in a Sarbanes-Oxley world. Academy of Business and Economics Journal, 56-74.

Post, C. and Byron, K. (2015). Women on boards and firm financial performance: a metaanalysis. Academy of Management Journal, 1546-1571.

Post, C., Rahman, N. and Rubow, E. (2011). Green Governance: boards of directors' composition and environmental corporate social responsibility. Business and Society, 189-223.

Quality Of Earnings. (n.d.). Retrieved from Investopedia.com: http://www.investopedia.com/terms/q/qualityofearnings.asp

Rhode, D. and Packel, A. K. (2014). Diversity on Corporate Boards: How Much Difference Does Difference Make? Delaware Journal of Corporate Law (DJCL), 377-426.

Richard, O. C. (2000). Racial Diversity, Business Strategy, and Firm Performance: A Resource-Based View. Academy of Management Journal, 164-177.

Ruigrok, W., Peck, S. and Tacheva, S. (2007). Nationality and gender diversity on Swiss corporate boards. Corporate Governance: An International Review, 546-557.

Shu Lin, M. P. (2011). The Role of the Internal Audit Function in the Disclosure of Material Weaknesses. The Accounting Review, 287-323. 
Hashim, Ahmed \& Huey | Board Diversity and Earning Quality

Sivaramakrishnan, S. and Yu, S. C. (2008). On the Association Between Corporate Governance and Earnings Quality. AAA 2008 Financial Accounting and Reporting Section (FARS) Paper, 1-36.

Sonnenfeld, J. (2002). What makes great boards great? Harvard Business Review, 106113.

Stuart, S. (2012). Boardroom diversity survey. Chicago, IL: Spencer Stuart.

Ujinwa, A., Okoyeuzu, C., and Nwokoby, I. . (2012). Corporate board diversity and firm performance: Evidence from Nigeria. Review of International Comparative Management, 13(4).

UNDP. (2011). Jordan Small Businesses and Human Development. Retrieved from Jordan Human Development Report 2011: www.undp-jordan.org

Walt, N.T. and Ingley, C.B. . (2003). Board dynamics and the influence of professional background,gender and ethnic diversity of directors. Corporate Governance: An International Review, 218-234. 